\title{
Bayrak Törenlerinde Okul Müdürlerinin Yaptığı Konuşmaların Söylem Analizi
}

\author{
DOI: $10.26466 /$ opus. 476594 \\ Ramazan Asar $^{*}$ - Ahmet Arifoğlu ${ }^{* *}$ \\ " Doktora Öğr., Hacettepe Üniversitesi, Eğitim Bilimleri Enstitüsü, Ankara/Türkiye \\ E-Posta: ramazanasar@gmail.com ORCID: 0000-0001-7176-5391 \\ ${ }^{* *}$ Doktora Öğr., Hacettepe Üniversitesi, Eğitim Bilimleri Enstitüsü, Ankara/Türkiye \\ E-Posta: axarif@gmail.com \\ ORCID: 0000-0002-6834-6556
}

\section{Öz}

Bu çalışmada okul müdürlerinin, okullarda pazartesi günleri ders başlamadan önce ve cuma günleri ders bitiminden sonra yapılması zorunlu olan bayrak törenlerinde yaptıkları konuşmalarının incelenmesi amaçlanmıştır. Bu amaçla araştırmada nitel araştırma yaklaşımı benimsenmiş, okul müdürlerinin hangi konularda konuşmalar yaptıkları ve mesajların nasıl ilettiklerinin incelenmesinde söylem analizi tekniği kullanılmışıı. Araştırma 2015-2016 öğretim yılının ikinci döneminde Ankara ilinde gerçekleştirilmiştir. Çalışma grubu için Altındağ, Gölbaşı ve Keçiören ilçelerinden birer okul belirlenmiştir. Okullar sırasıyla ilkokul, ortaokul ve lise düzeyindedir. Veriler araştırmacılar tarafından okullara gidilerek, gözlem ve ses kaydı yapılarak toplanmıştır. Okul müdürlerinin her törende konuşma yapmadıkları görülürken, en fazla konuşma yapanın lise okul müdürü en az konuşma yapanın ise ortaokul müdürü olduğu bulunmuştur. Okul müdürlerinin hitap ettikleri kişiler ve hitap şekillerinin farklılaştı̆̆ı gözlenmiştir. Ayrıca okul müdürlerinin törenlerde; duyuru yapma, uyarılarda bulunma ve disiplini sağlama konuları üzerinde konuşmalar yaptığı sonucuna ulaşılmıştır.

Anahtar Kelimeler: Bayrak töreni, müdür konuşması, tören konuşmaları, söylem analizi 


\title{
Discourse Analysis of The Speeches of School Principals In Flag Ceremonies
}

\begin{abstract}
In this study, it was aimed to investigate how school principals talk about what they do during the flag ceremonies, which must be done before school starts on Mondays and after school on Fridays. For this purpose, a qualitative research approach has been adopted in the research, and a discourse analysis technique has been used to examine what principals are talking about and how they communicate their messages. The research was carried out in the province of Ankara in the second semester of 2015-2016 academic year. For the study group, one school was determined from the districts of Altındă̆, Gölbaşı and Keçiören. Schools are in primary, secondary and high school respectively. The data were collected by researchers by going to schools, observing and voice recording. School principals were found not to speak at every ceremony, but it was found that the person who made the most speeches was the head of the high school and the person who gave the least speeches was the head of the middle school. It has been observed that the types of addressees and addresses addressed by school principals differ. In addition, in the ceremonies of the school principals; To make announcements, to be warned, and to provide discipline.
\end{abstract}

Keywords: Flag ceremony, principal speech, ceremony speeches, discourse analysis 


\section{Giriş}

Türkiye'deki resmi ve özel okullarda Milli Eğitim Bakanlığı Bayrak Törenleri Yönergesi'ne göre, hafta içerisinde ilk ders başlangıcından önce ve son ders bitiminden sonra bayrak töreni yapılması zorunludur. Yönergeye göre okul müdürünün bayrak törenlerinde konuşma yapması ise zorunlu değildir. Fakat yine de konuşacaksa, konuşmasını bayrak töreninden önce tamamlaması gerektiği belirtilmektedir. Okul müdürünün bu törenlerde konuşma yapma zorunluluğu bulunmamasına rağmen çeşitli konularda konuşmalar yapması, okul müdürünün söylediklerini önemli hale getirmektedir. Bu konuşmalar, İstiklal Marşı töreni için bir araya gelen insanlara hitap edildiği için tek taraflı konuşmalardır. Bu yönüyle öncelikle öğrencilere yönelik olan ve herkesin dinlemesine açık olan bayrak törenlerinin; okulun bülteni görevini gördüğü ve halk ile iletişimini sağlayan konuşmalara sahne olduğu görülmektedir.

Bayrak törenlerine, o sirada okulda bulunan bütün öğrenci, öğretmen ve görevlilerin katılma zorunluluğu bulunmaktadır. Töreni okul yöneticileri ile beraber öğretmenler de yürütebilmektedir. Fakat törenin yürütülmesinden okul müdürü sorumludur. Törenler, zorunlu haller dışında okulun bahçesinde yapılmaktadır. Törenlerde eğer bir konuşma yapılacaksa, İstiklal Marşı okunmadan önce bitirilmesi gerekmektedir (Milli Eğitim Bakanlığı, 2007). Okul müdürleri, okulların yönetiminden sorumlu kişiler olduğu için onların konuşmaları okul açısından önem taşımaktadır. Bayrak törenleri okulda bulunan herkese hitap edebilme imkanı verdiğinden okul müdürleri için önemli bir fırsattır.

Bayrak törenlerinde okul müdürlerinin konuşma zorunluluğu bulunmamasına rağmen bu törenlerin konuşma yapmak için değerlendirilmesi, okul müdürlerinin iletmek istediği bazı mesajların varlığını göstermektedir. Bayrak törenlerinin belirli günlerde yapılıyor olması da okul müdürlerinin yapacağı konuşmaya hazırlık yapmasını sağlamaktadır. Dolayısıyla okul müdürlerinin, konuşacakları zaman kullanacakları söylemleri özel olarak belirledikleri söylenebilir. Bu bağlamda okul müdürlerinin söylemlerinin dikkate alınması gerekmektedir. Bu nedenle çalışmanın konusunu okul müdürlerinin bayrak törenlerinde yaptığ konuşmaların incelenmesi oluşturmaktadır. 
Bu çalışmada okul müdürlerinin bayrak törenlerinde yaptıkları konuşmaların incelenmesi amaçlanmıştır. Bunun için okul müdürlerinin söylemleri üzerinde durulmuştur. Bu yüzden konuşmalarda sadece neyin ifade edildiğini değil aynı zamanda nasıl ifade edildiğini de ortaya koymak için söylem analizi tekniği kullanılmıştır. Araştırmanın problem cümlesi; Okul müdürleri bayrak törenlerinde nasıl konuşmalar yapmaktadir?

Araştırmanın alt problemleri ise;

1- Okul müdürleri bayrak törenlerinde hangi konularda konuşma yapmaktadir?

2- Okul müdürleri bayrak törenlerindeki konuşmalarında mesajlarını nasil iletmektedir?

\section{Okul Yönetiminde İletişim}

Fikir ve söylemlerin hem aktarılmasını hem de anlaşılmasını ifade eden iletişim (Robbins ve Judge, 2013), okul yaşantısının büyük bir kısmını oluşturmaktadır (Hoy ve Miskel, 2012). İletişim, yönetim süreçleri arasinda yer almaktadır (Aydın, 2014). Örgütlerde yöneticilerin genel iş yükü arasında en fazla zamanı da iletişim almaktadır (Lunenburg ve Ornstein, 2013). Ayrıca okul müdürü iletişim sürecini genellikle tek başına yürüterek okulu temsil etmektedir (Karakaya ve Uluğ, 2011). Bu nedenle okulda etkili bir yönetim için okul müdürünün etkili bir iletişim sergilemeye ihtiyacı bulunmaktadır.

İletişim, bir kaynaktan alıcıya mesajın iletilmesi sürecidir (Robbins ve Judge, 2013). Aydın'a (2014) göre bireyin çevresini anlama, değiştirme ve kontrol etme amacıyla kullandığı en önemli yollardan birisi iletişimdir. Eğitimin amaçlarının gerçekleştirilerek bireylere istenilen davranışların kazandırılabilmesi için etkili bir iletişime gerek duyulmaktadır (Çelikten, 2004; Gökçe ve Baskan, 2012). İletişim, bunu sağlayacak önemli bir faktördür (Çelikten, 2001a). Yöneticiler, iletişim sürecini, yönetsel faaliyetleri yerine getirmek ve etkili olmak için kullanmaktadır (Çelikten, 2001b; Hoy ve Miskel, 2012). Buradan anlaşılacağı üzere iletişim, etkili bir yönetim sergileyerek eğitimin amaçlarının yerine getirilmesini sağlayan etkili bir araçtır. Dolayısıyla okul müdürlerinin, yönetim süreçlerinden birisi olan iletişimi göz ardı edebilmesi mümkün değildir. 
Yöneticilerin etkili bir iletişim becerisine sahip olması, örgüt amaçlarının gerçekleşmesine büyük katkı sağlamaktadır (Asar ve M. Çelikten, 2016). Dahası okulun "etkili okul" olabilmesi için yöneticilerin, öğretmenlerle etkili iletişim kurması beklenmektedir (Asar ve Y. Çelikten, 2016). Diğer yandan yöneticilerin etkili bir iletişim becerisine sahip olmamasının; iş tatmin düzeyinin düşmesi (Karcıoğlu, Timuroğlu ve Ç1nar, 2009), motivasyon düşüklüğü (Özgan ve Aslan, 2008) ve düşük performans gösterme (Tanrıverdi, Adıgüzel ve Çiftçi, 2010) gibi olumsuz sonuçları bulunmaktadır. İletişimin yönetimdeki yeri nedeniyle etkili bir iletişim becerisine sahip olmak, temel bir yöneticilik becerisi olarak görülmektedir (Lunenburg ve Ornstein, 2013; Aydın, 2014). Şahin'in (2000) araştırmasında da etkili iletişim becerisinin, okul müdürlerinin sahip olması gereken bir yeterlik olduğu ortaya konmuştur. Okul müdürü etkili kararlar alsa bile bunu uygulayabilmesi etkili bir iletişim becerisi ile mümkün olmaktadır (Şekerci ve Aypay, 2009).

\section{Bir iletişim aracı olarak bayrak törenleri}

Okul müdürleri görevlerini yerine getirirken öğretmen, öğrenci ve velilerle iletişim kurmak zorundadır (Lunenburg ve Ornstein, 2013). Okul müdürlerinin, okul ile ilgili bazı beklentileri olduğu için bunu bir şekilde iletmesi gerekmektedir. Robbins ve Judge'a (2013) göre iletişim kurmanın yeri ve zamanı ile birlikte iletişim için hangi kanalın kullanılacağı da önemlidir. Okulda yapılan törenler, insanları bir araya getirerek okul kültürünün oluşmasında önemli bir yere sahiptir (Şahin, 2013). Törenler, okul müdürünün iletişim kurmak zorunda olduğu insanlara ulaşma imkanı sağlaması ve ne zaman yapılacağının belli olması nedeniyle okul müdürlerinin iletmek istediği mesajlar için önemli bir fırsattır. Bu nedenle okul müdürlerinin etkili bir yönetim sergilemek amaciyla bayrak törenlerini çok iyi değerlendirmesi gerekmektedir.

Okullarda insanlar, farklı amaçlarla etkileşimde bulunmaktadır. Hoy ve Miskel'e (2012) göre bu etkileşim, tek yönlü ve çift yönlü iletişim düzleminde gerçekleşmektedir. Hoy ve Miskel; tek yönlü iletişimin tek taraflı, çift yönlü iletişimin ise karşılıklı olduğunu ifade etmektedir. Okul müdürleri, mesajlarını iletmek için hem tek yönlü hem de çift yönlü iletişimi kullanmaktadır (Lunenburg ve Ornstein, 2013). Bayrak törenlerinde 
okul müdürleri belirledikleri mesajları karşı tarafa iletmek için konuşma yaptığı için iletişim genellikle tek yönlüdür. Bununla birlikte bayrak törenlerinde yapılan konuşmalar, okul müdürünün yönetimde neleri önemsediği ve okuldaki problemler hakkında fikir vermektedir.

\section{Okul müdürünün iletişim tarzı}

Okul müdürlerinin öğretmen, öğrenci ve velilerle iletişiminde yukarıdan aşağıya doğru bir iletişim söz konusudur. Hoy ve Miskel'e (2012) göre yukarıdan aşağı doğru bir iletişim kolaydır fakat aşağıdakilerin mesajları yanlış anlaması riski bulunmaktadır. Bunun için yöneticilerin iki yönlü iletişim kanalı oluşturarak geri bildirim alması gerektiğini vurgulamaktadırlar. Okul müdürlerinin her ne kadar çift yönlü iletişimi kullanması beklense de zaman zaman tek yönlü iletişimi de kullanmaktadır. Törenlerde yapılan konuşmalarda geri bildirim alma imkanı çok az olduğu için okul müdürleri tek yönlü iletişim kurmak zorunda kalmaktadır. Bu da okul müdürlerinin iletişim becerisiyle birlikte mesajların nasıl iletildiğini gösteren iletişim tarzını da önemli hale getirmektedir.

Yöneticilerin yaptığı her şey iletişim içermektedir. Çünkü bir yönetici bilgi akışı olmadan strateji oluşturamaz ve karar veremez (Robbins, Decenzo ve Coulter, 2013). Yönetim ile ilgili kararların hayata geçmesi iletişim aracılığıyla sağlandığı için yöneticilerin insanlarla nasıl iletişim kurdukları onların yönetim tarzını da ortaya koymaktadır. Günenç'in (2014) çalışmasında başarılı bir iletişim için yöneticilerin iletişim tarzının önemli olduğu vurgulanmaktadır. Yöneticilerin iletişim tarzı ile ilgili yapılan birçok farklı araştırma da iletişim tarzının yönetim açısından önemini ortaya koymaktadır (Erkuş ve Günlü, 2009).

Okul müdürleri, iletişim için farklı kanallar kullanmakta ve farklı imkanları değerlendirmektedir. Bayrak törenleri de okul müdürlerinin değerlendirdiği bir iletişim kanalıdır. Okul müdürünün bayrak törenlerini nasıl kullandığı, insanlarla hangi konularda iletişim kurmak istediğini göstermektedir. Okul müdürlerinin mesajlarını nasıl ilettiği ise onların iletişim tarzını, dolayısıyla yönetim tarzını göstermektedir. 


\section{Söylem Analizi}

Söylem, bir olguyu belli bir yolla temsil ederek diğer olgular arasındaki ilişkileri belirtme biçimidir (Baş ve Akturan, 2013). Söylem analizi ise bir insanın sadece ne düşündügünü göstermekten ziyade söylenen sözün hangi sosyal gerçeklikte söylendiğini resmeden nitel bir yaklaşımdır (Yin, 2011). Çoğu insan söylem analizini dilbiliminin bir alt alanı olarak tanımlayabilir. Ancak söylem analizi sadece dilin araştırılması değil insanların gerçek hayatta farklı amaçlarla onu nasıl kullandıklarına odaklanmaktadır (Jones, 2012).

Söylem analizi; psikoloji, sosyoloji, antropoloji, felsefe, dilbilim, edebiyat, medya ve iletişim çalışmaları gibi farklı disiplinlerden beslenerek gelişen ve bunların teorik görüşlerine dayanan bir analiz tekniğidir (Potter ve Wetherell, 1987). Psikoloji, sosyoloji, bilişim ve felsefe gibi bilim dallarına nispeten yeni bir dil disiplini olan söylem analizi, bu bilim dalları ile kesişmektedir. Bu bilimler farklı amaçlarla söylem analizini kullanır (Brown ve Yule, 1983). Söylem analizinde asıl amaç, yazılı veya sözlü bir söylemin adlandırılması veya yorumlanmasıdır. Her türlü konuya ilişkin söylem analizi yapılabilmektedir. Söylem analizinin; politika, stratejik yönetim, ideoloji ve pazarlama gibi geniş bir konu yelpazesi vardır (Baş ve Akturan, 2013).

Söylem analizi farklı sosyal alanlarda çok farklı tip çalışmaların keşfedilmesinde kullanılan disiplinler arası bir yaklaşımdır (Jorgensen ve Phillips, 2002). Bu açıdan söylem analizinin bütünleşmiş tek bir teori, uygulama ve metot olmaktan ziyade farklı disiplinler ve araştırma gelenekleriyle yürütülen, heterojen özelliğe sahip nitel bir araştırma yöntemi olduğu söylenebilir (Tonkiss, 2006). Söylem analizinde, incelenen metin ya da dokümandaki sayıltı, anlam ve değerlerde zaten var olan sosyal kategorilere dikkat çekilir. Dil incelenen olayın önemli bir öğesi olduğu için olay veya fenomen onu açıklayan dilden ayrılmaz (Balcı, 2015). Söylem analizi sosyal olaylar ve ilişki yapılarının anlaşılmasında dilin “önemli bir analiz birimi” olduğu düşüncesine dayanır (Özdemir, 2010).

Söylem analizi her durum ve konuda uygulanabilmektedir. Hiçbir teknoloji veya parasal kaynak olmadan da yapilabilmesi bir avantaj olarak değerlendirilmektedir (Balc1, 2015). Phillips ve Hardy (2002), ortaya çıkan yeni konuların ancak söylem analizi ile derinlemesine incelenebile- 
ceğini söylemektedir. Söylem analizi, insan davranışının konuşulmayan ve bilinmeyen yönlerini ortaya çıkarabilmesi açısından dil ve söylemin işlevinin anlaşılmasını sağlamaktadır (Morgan, 2010).

\section{Yöntem}

Bu çalışmada okul müdürlerinin, haftanın ilk ve son günü okul bayrak törenlerinde yaptıkları konuşmalar incelenmiştir. Bu kapsamda araştırmada nitel araştırma yaklaşımı benimsenmiş ve verilerin incelenmesinde söylem analizi tekniği kullanılmıştır. Araştırma verilerinin toplanması tepkisiz ölçüm özelliği göstermektedir. Tepkisiz ölçümler, incelenen insanların bir çalışmanın parçası olduklarından habersiz olduğu ölçüm gruplarıdır (Neuman, 2013). Bu sayede araştırma verilerinin kendi doğallığı içinde toplanması hedeflenmiştir. Çalışmada; nitel bir yaklaşım olan söylem analizi tekniği kullanılarak okul müdürlerin yaptıkları tören konuşmalarının konuşma temaları belirlenmiş, törenlerin yapılış şekli ve düzeni değerlendirilmiştir.

Söylem analizinde örneklemin büyük olması, araştırmanın başarılı olduğunu göstermemektedir. Söylem analizinde örneklem büyüklüğü değil araştırma soruları önemli görülmektedir (Sözen, 1999). Örneklem sayısını genellikle araştırmanın amacı ve veri kaynağı belirlemektedir (Balc1, 2013). Söylem analizinde örneklemin, araştırılan konuyu temsil etmesi önemli olduğundan; örneklem olarak sadece insanlar değil, gazetelerde çıkan haberler, videolar, sosyal medya veya kayıt cihazlarıla kaydedilmiş konuşmalar da seçilebilmektedir (Treadwell, 2013; Baş ve Akturan, 2013). Kısaca bir söylem üreten her türlü kaynak söylem analizinde kullanılabilmektedir (Gür, 2013). Bu çalışmada da veri olarak okul müdürlerinin bayrak törenlerindeki konuşmaları alınmıştır.

Söylem analizi metin veya söylemdeki dil ile ilgilendiği için; söylem analizindeki örnekleme süreci diğer tekniklerin örnekleme sürecinden farklıdır. Söylem analizinde kimin söylediği değil, ne söylendiği önemli olduğundan kişilere yönelik bir örnekleme yapılmamaktadır. Bu nedenle küçük bir örneklem grubu söylem analizi için yeterli olmaktadır. Çünkü büyük bir örneklem, araştırmanın yönetilmesini zorlaştırmakta ve araştırmaya önemli katkıları da bulunmamaktadır (Elliot, 1996 akt: Baş ve Akturan, 2013). Ayrıca birkaç insandan muhtemelen çok sayıda dile ait 
örnek çıkacağından, küçük örneklem veya birkaç kişi genellikle araştırma için yeterli olmaktadır (Balcı, 2013; Potter ve Wetherell, 1987). Çalışma grubunu oluşturmak için Altındağ, Gölbaşı ve Keçiören ilçelerinden birer okul belirlenmiştir. Okullar sırasıyla ilkokul, ortaokul ve lise düzeyindedir. Dolayısıyla her öğretim düzeyinden bir okul müdürü, çalışma grubunu oluşturmuştur.

Araştırma 2015-2016 öğretim yılının ikinci döneminde Ankara ilinde gerçekleştirilmiştir. Veriler araştırmacılar tarafından şubat ve haziran ayları arasında okullara gidilerek, ses kaydı yapılarak toplanmıştır. Konuşmaların hangi bağlamda gerçekleştirildiğini belirlemek amacıyla aynı zamanda gözlem de yapılmıştır. Balcı'ya (2013) göre gözlem, katılımcıların amaçlarına ulaşmak ve insanlar arası ilişkilerinde kendini ifade etmede dili nasıl kullandıklarını ortaya koyması bakımından söylem analizinde kullanılmaktadır. Gözlemler eşliğinde toplanan ses kayıtları yazıya aktarılmış ve sonrasında analiz edilmiştir.

\section{Bulgular}

Okullarda yapılan bayrak törenlerinde genellikle okul müdürlerinin konuştuğu görülmüştür. Törenlerde okul müdürü haricinde bazen müdür yardımcıları da konuşurken, müdür yardımcılarının genellikle töreni yönetmek için konuştuğu gözlenmiştir. Okul müdürleri okulların karar verici kişileri olduğu için okuldaki eğitim öğretimin işleyişini ilgilendiren konuşmaları, okul müdürlerinin yaptığı görülmektedir. Bütün öğrenci ve öğretmenlerin bir araya geldiği törenleri okul müdürlerinin bir fırsat olarak değerlendirmeye çalıştığı gözlemlenmiştir.

Okullarda haftanın başlangıcı ve bitiminde yapılan törenlerde sadece İstiklal Marşı okunmamaktadır. Okul müdürleri bu törenleri değerlendirmekte, çoğu zaman kısa da olsa, dinleyenlere hitap etmektedirler. Okul müdürlerinin bu konuşmalarında hitap ettikleri kişiler genellikle öğrenciler olmakla birlikte; zaman zaman konuşmayı dinleyen öğretmenler ve veliler de olabilmektedir. Çalışmada toplanan verilere göre, okul müdürleri öncelikle öğrencilere hitap etmektedir. Fakat ilkokulun müdürünün velilere de hitap ettiği görülürken, lise okul müdürünün konuşmalarında zaman zaman öğretmenlere de hitap ettiği gözlenmiştir. 
Bu çalışmada okul müdürlerinin belirli bir zaman dilimindeki konuşmaları incelenmiştir. Konuşmalar incelendiğinde en çok konuşma yapan okul müdürünün lise okul müdürü, en az konuşma yapan okul müdürünün ise ortaokul okul müdürü olduğu bulunmuştur. Okul müdürlerinin konuşma yaparken çevre şartlarından da etkilendiği görülmüştür. Özellikle soğuk havalarda okul müdürlerinin önemli bir mesele olmadan konuşma yapmadıkları, konuşma yaptıklarında da kısa tuttukları gözlenmiştir. Okul müdürlerinin hitap ettikleri kişiler ve hitap şekillerinin de farklılaştığı görülmüştür. Okul müdürlerinin nasıl konuşmalar yaptığı ve dinleyenlere nasıl hitap ettiği ise törenlerin kullanım amacına göre değişmektedir. Okul müdürlerinin yapılması zorunlu olan bayrak törenlerinin öncesini, belirli amaçlara göre konuşma yapmak üzere değerlendirdiği gözlenmiştir. Çalışmanın analiz kısmında okul müdürlerinin bütün konuşmaları incelenerek, konuşmaların tamamından ortaya çıkan genel ifadeleri yansıtacak örnek cümleler seçilmiştir.

\section{Okul müdürlerinin konuşma yaptığı konular}

Okul müdürlerinin yaptığı konuşmalar, bayrak törenlerini iletişim amacıyla nasıl kullandıklarını göstermektedir. Araştırmanın birinci alt problemi "Okul müdürleri bayrak törenlerinde hangi konularda konuşma yapmaktadır?" sorusuna ilişkin bulgulara bu başlık altında yer verilmiştir. Okul müdürlerinin bayrak törenlerini; bazı meseleleri duyurmak, uyarı yapmak ve okulda disiplin sağlamak amacıyla değerlendirdikleri tespit edilmiştir.

Okul müdürlerinin duyuru yapma amacıyla konuşmaları: Duyuru; "Herhangi bir olguyu, bir işi, bir durumu duyurmak için yayımlanan yazll veya sözlü haber, ilan" (Türk Dil Kurumu [TDK], 2016) anlamına gelmektedir. Okul müdürleri törenleri, bazı konuları bütün öğrenci ve öğretmenlere duyurmak için bir fırsat olarak görmektedir. Normalde bunu tören dişında da yapma imkanına sahipken, okuldaki öğrenci ve öğretmenlerin tamamına hitap etme fırsatı törenlerde ortaya çıkmaktadır. Okul müdürlerinin bazı konularda bizzat kendilerinin duyuru yapması ile konunun önemine dikkat çekmek istediği söylenebilir. Okul müdürle- 
rinin yapmış olduğu duyurular, konuşma öncesinde planlandığ1 gibi tören sırasında ortaya çıkan bir durumla ilgili de olabilmektedir.

İlkokul müdürü bir tören sırasında bulunan kıymetli eşya için velilere hitap eden bir duyuruda bulunmuştur. Okul müdürü, "Sayın veliler, kıymetli eşyalarından kaybedenler varsa okul idaresine başvursunlar." ifadesinde kıymetli eşyasını kaybeden kişiyi, bulan kişiye yönlendirmemiş ve bulunan eşyanın sorumluluğunu üzerine almıştır. Burada kıymetli eşyayı bulan kişinin de törenin, herkese hitap edebilme imkanını kullanmak isteyerek buradan duyurmaya çalıştığı görülmektedir. Ayrıca kıymetli eşyanın okul idaresine teslim edilmesi de okul idaresinin çevresine güven verdiğini göstermektedir. Duyurunun devaminda yer alan "Kıymetli eşyalarından okul bahçesinde, yakılarında kaybeden var ise okul idaresine başvursunlar." ifadeye göre kıymetli eşyanın okul müdürünün sorumluluk alanı olan okul bahçesinin dışında bulunma ihtimali de vardır. Buna rağmen polise de verilebilecek olan kıymetli bir eşyanın okul müdürüne teslim edilmesi, çevredeki insanların okul idaresine güven duyduğunu göstermektedir. Yine ilkokulun müdürü daha önce planlanmış bir nedenle öğrencilerin okula her zaman geldikleri vakitten farklı bir vakitte gelmelerini "pazartesi günü saat 12'ye 10 kala burda olacaksını" ifadesiyle kısa ve net bir şekilde duyurmuş, buna rağmen hitap ettiği öğrencilerin yaşça küçük olmaları nedeniyle anlayıp anlamadıkları konusunda tereddüde düşerek öğrencilere "Anlaşıldı mı?" sorusunu yöneltmiştir. Öğrenciler her ne kadar hep bir ağızdan "anlaşıldı" deseler de daha fark1 bir cevap beklenmediği açıtır.

Araştırma için veri toplama sürecinde ortaokul müdürünün çok fazla konuşma yapmadığ1 gibi herhangi bir konuda da duyuru yapmadığ1 görülmüştür. Lise okul müdürünün ise genellikle öğrencilere, eğitim öğretimi doğrudan ilgilendiren konularda duyurularda bulunduğu gözlenmiştir. Bunlardan birisi, destekleme ve yetiştirme kursları müracatları üzerine olmuştur. Okul müdürü "Ayın 18'ine kadar sizlere verilmiş olan EBA şifreleri ile e-kurs modülüne giriyorsunuz, orda anasayfada sisteme okul girişi var, kurs merkezi girişi var bir de öğrenci girişi var." ifadesi hangi tarihe kadar müracat etmeleri gerektiğini vurgularken, nereden müracat edileceğini de belirtmektedir. Fakat müracat aşamalarını açıkladığ “ “Ö renci girişinden açıyorsunuz, hangi sınıftaysanı sınıfını işaretle sonra da almış olduğunuz daha doğrusu alacağınız dersleri işaretliyorsunuz." ifadelerinden 
sonra "Karışıklı̆̆a meydan vermemek için şu ana kadar devam etmiş olduğunuz kursların sistemini değiştirecek değiliz. Aynı öğretmenleri, aynı ders saatlerini seçerek ileriye devam edeceğiz." ifadeleri gelmektedir. Bu ifadelerden okul müdürünün niyetinin öğrencilere müracatlarında yardım etmek değil, onları yönlendirmek olduğu anlaşılmaktadır. Okul müdürü öğrencilerin tercihini değil, kendi tercihini ön plana çıkarmaktadır.

Okul müdürlerinin uyarma amaçlı konuşmalar yapması: Uyarı; "Herhangi bir konu, sorun üzerine ilgi çekme, ikaz, ihtar, tembih" (TDK, 2016) anlamına gelmektedir. Okul müdürleri okulda yolunda gitmeyen işlerle ilgili uyarılarda bulunmuştur. Uyarıların çoğunlukla, ortaya çıkan sorunlar üzerine ilgi çekme amaçlı olduğu gözlenmiştir. Okul müdürlerinin uyarıları bazen henüz meydana gelmeyen durumlarla ilgili önleme amaçlı iken bazen de okulu doğrudan etkilemeyen konularda tembih niteliğindedir. Okul müdürleri uyarı niteliğindeki konuşmalarında, okulun işleyişini düzenleyen kurallara vurgu yapmaktadır. Bunlar daha önce bilinen kurallar olduğu gibi yeni ortaya çıan durumlara uyum sağlanmasını amaçlayan kurallar da olabilmektedir. Okul müdürleri öğrenci, öğretmen ve velileri okulda uyulması gereken kurallar konusunda uyarmaktadır. Okul müdürleri bazı kurallara uyulmasını beklerken, davranışların düzelmemesi durumunda üslubunun değişmeye başladığı görülmüştür.

İlkokulun müdürü törene geç gelen öğrencilere yönelik yapmış olduğu uyarılar dikkat çekmektedir. Okul müdürünün, "Geç kalanlar burda sıra olsun. Çocuklar bu seferlik affediyorum. İsimlerinizi alacağım bi dahaki sefer bakacağım, aym kişileri var mı diye." konuşması içerisinde bir eylem de barındırmaktadır. Okul müdürü geç gelen öğrencileri diğer öğrencilerden ayırırken, bu seferlik affettiğini söylemekte ve aynı davranışın tekrarı durumunda affetmeyeceğini ima etmektedir. Bunu pekiştirmek için de öğrencilerin isminin alınarak aynı öğrencilerin bir daha aynı davranışı sergilemesini önlemeyi amaçlamaktadır. Okul müdürü konuşmasının devamında "Bundan sonra erken yatıp erken kalkıyorsunuz. Anlaşıldı mı?" diyerek, öğrencilerin okula geç kalmamaları için ne yapmaları gerektiği konusunda tembihte bulunmaktadır. Okul müdürü her ne kadar öğrencilerin ileride bir yaptırım ile karşılaşabileceği izlenimi verse de 
önceliğinin öğrencilere ceza vermek değil, istenmeyen davranışın tekrar edilmesini önlemek olduğu anlaşılmaktadır.

Lise okul müdürü bir konuşmasında yetiştirme kursları hakkında uyarılarda bulunmuştur. "İkinci dönem müracatlarının ayın 18'ine kadar girilmesi gerekiyor. Sonra geliyor öğrenci benim fikrim değişti işte katılacam falan, böyle yapmayalım. Size bunun duyurular yapıldı." ifadesinde okul müdürü daha önce duyurusunu yapmış olduğu yetiştirme kurslarında müracatların yetersiz kalması nedeniyle belirli bir tarihe kadar müracatların yapılması konusunda öğrencileri uyarmaktadır. "Zamanında bi işi yapmayı öğrenin. Ayın 18'i ise 18'ine kadar bu iş bitmiş olsun." ifadesinde ise okul müdürü daha önce yaşanmış sorunlara da dikkat çekmekte, başvuru tarihi geçmiş olmasına rağmen fikrinin değiştiğini öne sürerek kursa katılmak için kendisine gelen öğrencilerden şikayet etmektedir. Öğrencilere daha önce duyuru yapıldığını belirterek, işlerin zamanında yapılmas1 gerektiği tembihinde de bulunmaktadır. Ancak okul müdürü öğrencilerden zamanında iş yapmayı öğrenmeleri gerektiğini vurgularken; "18'ine kadar bu iş bitmiş olsun" ifadesi tembih niteliğinde olduğu için, okul müdürü istediği bir durum olmamasına rağmen ayın 18'inden sonra da müracaatların yapılabileceği anlaşılmaktadır.

Okul müdürlerinin konuşmalarnda disiplin vurgusu: Disiplin; "Bir topluluğun, yasalarına ve düzenle ilgili yazll veya yazısız kurallarma titizlik ve özenle uyması durumu, sıkı düzen, düzence, düzen bağı, zapturapt" (TDK, 2016) anlamına gelmektedir. Okul müdürlerinin konuşmalarından okuldaki düzene çok önem verdikleri anlaşılmaktadır. Dolayısıyla törenlerde yapılan konuşmalardaki disiplin vurgusu kendisini hissettirmektedir. Okul müdürlerinin kurallara uyulmasını sağlamak için çeşitli önlemler aldığı ve bu önlemleri de konuşmalarıyla hayata geçirmek istediği gözlenmiştir. Okul müdürlerinin disiplin konusunda kendi yetki alanları içerisinde kalan konularda bazı kurallara uyulmasını beklemekte, bazen de yeni kurallar koymakta olduğu görülmektedir.

İlkokul müdürü "ders başladığı an sinıfında, kitabın masanın üzerinde açılmış olarak duracak." ifadesi ile öğretmenleri gelene kadar geçen zamanda, öğrencilerin nasıl beklemeleri gerektiği konusunda kural koymuştur. Bu ifadeden öğrencilerin, öğretmenleri gelene kadar geçen zaman diliminde sınıfta disiplin sorunu çıkardıkları anlaşılmaktadır. Fakat 
dersten öğretmen sorumlu olması ve öğrencilerin dersin başlangıcından itibaren öğretmenleri nasıl beklemeleri gerektiğinin tarif edilmesi; öğretmenlerin derslere zamanında girmediklerini göstermektedir. Burada okul müdürünün şikayetçi olduğu durum aslında normal şartlarda öğretmenin derse zamanında girmesiyle çözülecek bir sorundur. Buna rağmen okul müdürü bu sorundan öğrenciler sorumluymuş gibi öğretmenlerden değil onlardan sorunu çözmelerini beklemektedir.

Lise okul müdürü İstiklal Marşı töreninin yapılmasında aksaklık farketmiş ve bu konuya hassasiyet gösterilmesini öğrencilerden istemiştir. Okul müdürü, "İstiklal marşı töreni pazartesi günü yapılır, 8'e 10 kala 5 kala burda olmamız gerekir. Mesela öğretmenlerimizin tek tek sınıf sınıf sizi çă̆ırması gerekmez demi çocuklar." ifadesi ile bir yandan tören zamanında öğrencilerin okulda olmasını isterken diğer yandan da tören zamanında okulda olan öğrencilerin sinıflardan çağırılmadan tören yerine gelmelerini beklemektedir. Konuşmasının devamında "Bi de soruyosunuz hava soğuk istiklal marşı okuyacak mıyız. Tarih dersi görüyorsunuz, Sarıkamış'ı bilirsiniz. 47 bin askerin soğukta donduğunu da bilirsiniz, şehit düştü̆̆̈̈nü." ifadeleriyle, her koşulda İstiklal Marşı'nın okunacağını belirtirken tarihten örnek vererek de bu konuda cinsiyet ayrımı yapmadan bütün öğrenci ve öğretmenlerden askeri bir disiplin beklemektedir.

\section{Okul müdürlerinin hitap şekli}

Okul müdürlerinin konuşma yaparken insanlara hitap etme şekli, onların nasıl bir iletişim tarzı benimsediğini göstermesi bakımından önemlidir. Bayrak törenlerinde mesajların nasıl iletildiği, yönetim görevinin nasıl yerine getirildiğini göstermektedir. Araştırmanın ikinci alt problemi "Okul müdürleri bayrak törenlerindeki konuşmalarında mesajlarını nasıl iletmektedir?" sorusuna ilişkin bulgulara bu başlık altında yer verilmiştir. İlkokulun okul müdürü tehdit edici, lise okul müdürü emir verici bir dil kullanırken ortaokul okul müdürü saygılı bir dil kullanmaktadır. İlkokulun okul müdürü, öğrencileri cezalandırma ile korkutarak mesajlarını iletmiştir. Ortaokulun okul müdürü, konuşmalarında istediklerinin gerekçelerini belirterek ikna yoluyla mesajlarını iletmiştir. Lise okul müdürünün ise emir verici bir dil kullanarak mesajlarını iletti- 
ği, kullandığı dilin zaman zaman insanları rencide edici olduğu görülmüştür.

İlkokulda öğrenim gören öğrenciler, yaşları küçük olmaları veya evlerinin okula uzak olması nedeniyle gidiş-gelişlerine genellikle velileri eşlik etmektedir. Böylece okul müdürünün konuşma yaptığı sırada öğrenci velileri de hazır bulunabilmektedir. Okul müdürünün bu durumu değerlendirerek konuşmalarında velilere de hitap ettiği görülmüştür. Okul müdürü öğrencilere hitap ederken, onların yaşça küçük olmaları nedeniyle anlaşılır ve kısa konuşmaktadır. Okul müdürü, öğrencilerin okula normal geliş saatlerinden farklı bir saatte gelmelerini istediği; " $p a$ zartesi günü saat 12'ye 10 kala burda olacaksinız" ifadesinde onların okulda olmaları gereken zamanı net bir şekilde ifade ederken, "Anlaşıldı mı?" sorusunu yönelterek söylediğinin anlaşıldığını teyit etme gereği duymuştur. İlkokul müdürü, öğrencilerin karışık ve uzun cümleleri anlayamayabileceğini hesaba katarak öğrencilere söylediklerinin anlaşıldığını teyit etmekte, çoğu zaman da doğrudan veya dolaylı şekilde velilere hitap etmektedir. Örneğin; "Velileriniz de burda söylüyorum. Okula futbol topuyla gelmeyin." ifadesinde okul müdürü öğrencilerden okula futbol topu getirmemelerini istemektedir. Fakat velilerin de orada hazır bulunduklarına vurgu yaparak onlardan, çocuklarının okul müdürünün talebinin daha iyi anlaşılması ve bu talebin yerine getirilmesi konusunda destek beklenmektedir. Okul müdürü bazen de "Sayın veliler" ifadesiyle başlayan cümlelerle öğrenciler yerine doğrudan velilerden taleplerde bulunmaktadır.

Ortaokul müdürünün çoğunlukla öğrencilere hitap ettiği gözlenmiştir. Ortaokul müdürü öğrencilerden doğrudan bir talebi yerine getirmelerini istemek yerine, kendilerinden istenilen davranışın nedenini de açıklamaktadır. Örneğin okul müdürü bayrak töreni için öğrencilerin sıra olmasını istediği bir konuşmada; "Ĕğer siz sıra olmazsanız, bayrak törenini yapamayız." öğrencilerden neden sıra olmalarını istediğinin açılamasını yapmıştır.

Çalışmada konuşmaları incelenen lise okul müdürünün, öğrencilerle beraber öğretmenlere de hitap ettiği gözlenmiştir. Okul müdürü öğrencilere genellikle emir verir tarzda hitap etmektedir. Örneğin okul müdürü kullanmış olduğu; "Sağlığınıza dikkat edin normal beslenmenizin dışındaki yiyecek, içeceklere yönelmeyin bu haftalarda onu söylüyorum. Hava şartları çok 
değişken, üzerinizi sağlam giyinin. Ayaklarınızdan başınıza kadar." ifadelerinde her ne kadar öğrencileri düşündüğünü göstermek istese de, öğrencilerden okulda olmadıkları zamanlarda da yapılacak ve onların özel hayatlarını ilgilendiren isteklerde bulunmaktadır. Üstelik bu isteklerini öğrencilere yöneltirken emir verir tarzda bir üslup kullanmaktadır. Okul müdürünün öğretmenlere hitap şekli ise meslektaşına hitap eder tarzda değil, üstün bir astına hitabı şeklinde olmaktadır. Fakat kamuya açık bir şekilde yapılan konuşmadaki bu hitap şeklinin, öğretmenleri rencide edici olduğu söylenebilir. Okul müdürü öğretmenlerle özel görüşerek söylemesi gereken şeyleri bayrak törenlerinde söylemektedir. Örneğin törene geç kalan bir öğretmenle özel konuşmak yerine, ona söyleyeceklerini öğrencilerin şahit olacağı şekilde yapmıştır. Okul müdürü öğretmene karş1; "Sevgili öğretmenim, okulun eğitim-öğretimi başlamadan heralde bi 10 dakka erken gelmek lazım ki eğitim-öğretimle ilgili çeşitli açıklamalar olabilir." ifadelerini kullanarak öğretmeni, görevini yerine getirme konusunda hassas davranması konusunda öğrencilerin karşısında uyarmıştır. Konuşmanın devamında; "Pazartesi günleri bildiğiniz üzere bayrak törenimiz var, istiklal marşımızı okuyoruz. Onun için hassasiyetlerinize teşekkür ediyorum sizin. Yani siz bu kurallara uymuş olmanı sebebiyle." ifadelerini kullanarak dolaylı olarak öğretmenin kurallara uymadığını vurgulamıştır. Bu nedenle okul müdürünün teşekkür etmesini de olumlu olarak değerlendirmemek gerekmektedir.

\section{Sonuç ve Tartışma}

Bu çalışmada Milli Eğitim Bakanlığına bağlı resmi eğitim kurumlarının ilkokul, ortaokul ve lise öğretim düzeyinde görev yapan okul müdürlerinin bayrak törenlerindeki konuşmaları incelenmiştir. Araştırma sonucunda okul müdürlerinin bu törenleri belirli amaçlarla konuşma yapmak için kullandığı görülmüştür. Bütün öğrenci ve öğretmenleri bir araya getiren törenler, okul müdürleri tarafından değerlendirilmeye çalışılmaktadır. İlkokul ve ortaokul müdürleri hava şartlarının dışarıda toplanmaya müsait olmadığı durumlarda, bayrak törenlerini okulun içerisinde yaptırmaktadır. Okul müdürlerinin konuşma yapma zorunluluğu bulunmadığından her törende konuşma yapmadıkları görülmüştür. Bu 
nedenle okul müdürlerinin kendilerini her zaman konuşma yapmak zorunda hissetmemeleri, yapılan konuşmaları önemli hale getirmektedir.

Okul müdürlerinin törenlerde; duyuru yapma, uyarılarda bulunma ve disiplini sağlama konuları üzerine konuşmalar yaptığı sonucuna ulaşılmıştır. Normal zamanlarda bir araya gelmesi zor olan; bütün öğrenci ve öğretmenlerin yanı sıra törende hazır bulunan velilerin varlığını değerlendirmek için törenler maliyetsiz ve etkili bir iletişim aracı olarak kullanılmaktadır. Okul müdürleri, bir yönetim süreci olan iletişimi göz ardı etmemektedir. Üstüner'in (2016) çalışmasında, sorunları erteleyen veya görmezden gelen yöneticilerin ilgisiz yönetim tarzı sergiledikleri ifade edilmektedir. Özgan ve Aslan (2008) ise iyi bir yönetim için yöneticinin iletişime önem vermesinin zorunlu olduğuna değinmektedir. Bu nedenle çalışmada, törenleri değerlendiren okul müdürlerinin ilgisiz bir tavırdan kaçınarak iletişimi önemli gördükleri anlaşılmaktadır.

Bayrak törenlerinin, daha önce planlanmış konularda duyuru yapmak amacıyla etkili bir şekilde değerlendirildiği görülmüştür. Yapılacak duyuruların törenden önce planlandığı anlaşlırken, tören sırasında ortaya çıkan durumlarla ilgili duyurular da yapılmaktadır. Daha önce yapılan bir duyurunun tekrarından ise sorunun hala çözülemediği anlaşılmaktadır. Fakat törenlerde genellikle yeni duyurular yapıldığı gözlenmiştir. Törenlerde sürekli aynı duyuruların yapılmamasından, törenlerdeki duyuruların amacına hizmet ettiği ve etkili olduğu anlaşılmaktadır.

Okul müdürleri konuşmalarında sorunlara dikkat çekmek için uyar1larda da bulunmaktadır. Okul müdürlerinin tembihlerde bulunarak olumsuzlukların yaşanmaması yönünde önlem almaya çalışması, sorunların çözümüne öncelik verildiğini göstermektedir. Okul müdürleri bazı hususlara dikkat edilmemesinin olumsuz sonuçlar doğurduğunu açıklayarak, uyarıların dikkate alınmaması durumunda kişileri bazı yaptırımlarla karşılaşabilecekleri konusunda bilgilendirmektedir. Üstüner'in (2016) çalışmasına göre okul müdürlerinin cezalandırıcı tavırları, onların otoriter bir yönetim anlayışı benimsediğine işaret etmektedir. Bu çalışmada ilkokul ve lise okul müdürlerinin, ceza ile korkutarak sorunları otoriter bir tarz ile çözmeye çalıştıkları görülmüştür.

Okul müdürleri konuşmalarında son olarak disiplin konusuna ağırlık vermektedir. Eğitim ve öğretimde aksaklıkların yaşanmaması için kurallara uyulması hususu vurgulanmıştır. Okul müdürleri, öğrenci ve öğ- 
retmenlerin herhangi bir uyarı olmaksızın kendiliğinden kurallara uymalarını beklemektedir. Herhangi bir disiplin problemi yaşanmaması için açılamalar yapmakta ve zaman zaman da kurallara uyulmasını sağlamak için yeni kurallar getirmektedir. Okul müdürleri törenlerde okul kurallarını duyurarak, öğrenci ve öğretmenlerin bu kurallara sürekli olarak dikkat etmeleri konusunda onları uyarmaktadır.

Araştırma sonucunda Milli Eğitim Bakanlığı Bayrak Törenleri Yönergesi'nde okul müdürlerinin konuşmalarının İstiklal Marşı okunmadan önce bitirilmesi gerektiği belirtilirken, araştırmaya dahil olan okul müdürlerinin bu konuda hassasiyet göstermedikleri dikkat çekmiştir. Bu durum okul müdürlerinin, kurallara uymalarını başkalarından beklerken kendilerinin buna riayet etmediklerini göstermektedir. Bektaş'in (2014) çalışmasında yöneticilerin sürekli kurallar koyuyor olmasının, örgüt içi iletişimi olumsuz etkilediği belirtilmektedir. Asar'a (2018) göre örgüt içi iletişimin iyi olmaması, çalışanların örgüt ile bağını zayıflatmaktadır. Ayrıca kendilerince yeni kurallar konulması ve buna uyulmasının beklenmesi, konumları nedeniyle okul müdürüne itaat edilmesinin beklendiğini göstermektedir (Üstüner, 2016). Okul müdürleri mevzuatta yasaklanmasına rağmen İstiklal Marşı okunduktan sonra da konuşmaktadırlar. Kendileri yazılı kurallara uymadıkları halde tek başlarına koydukları sözlü kurallara başkalarının uymasını beklemektedirler. Bu davranışlarıyla, okul yönetiminde otoriter bir tarza sahip olduklarını ortaya koymaktadırlar.

Okul müdürlerinin, konuşmaları ile okuldaki bazı sorunları çözmeye çalıştıkları görülmüştür. Sorunların bayrak törenlerindeki konuşmalara taşınması, örgüt içindeki iletişimle bunların çözülemediğini göstermektedir. Özellikle törenlerde öğretmenlere yönelik konuşmalar yapılması ve onların uyarılması, okul müdürü ile öğretmenler arasındaki iletişim eksikliğine işaret etmektedir. Törenlerde öğretmenlerin de bulunmasına rağmen sadece lise okul müdürünün öğretmenlere yönelik konuşma yaptığı görülmüştür. Normalde öğretmenlere hitap edilen meseleler, çift yönlü iletişimi gerektirmektedir. Fakat okul müdürü bunu tek yönlü iletişimle çözmeye çalışmaktadır. Buna sebep olarak okul müdürünün tören dışındaki zamanlarda öğretmenlerle sık iletişim kurmaması veya sorunların çözülemeyerek devam etmesi nedeniyle törenlerde de bu sorunlardan bahsetme gereği duyması gösterilebilir. Ayrıca okul müdü- 
rünün öğretmenleri rencide edici bir şekilde hitap ettiği görülmektedir. Bektaş'a (2014) göre yöneticinin iletişimdeki tavırları çalışanların örgüte bakışını belirlemektedir. Özgan ve Aslan'ın (2008) çalışmasında yönetici ile çalışanlar arasındaki iletişim eksikliğinin, çalışanların motivasyonunu düşürdüğü belirtilmektedir. Bununla bağlantılı olarak Erkuş ve Günlü (2009), iletişim eksikliğinin çalışanların performansını olumsuz etkilediğini vurgulamaktadır. Dolayısıyla okul müdürlerinin sayıca çok ve uzun konuşmalar yapmalarından da benimsedikleri iletişim tarzının sorunları çözemediği anlaşılmaktadır.

Okul müdürlerinin konuşmalarında genellikle öğrencilere hitap ettikleri görülmektedir. İlkokulun okul müdürünün öğrencilere hitap ederken onların gelişim düzeyine göre konuşmaya çalıştığı, uzun ve anlaşılması zor cümleler kurmak yerine kısa ve net ifadeler seçtiği görülmüştür. Ortaokul ve lise okul müdürlerinin ise öğrencilere yaptıkları konuşmalarda onların daha iyi anlamasını sağlamak için açıklamalarda bulundukları görülmüştür. İlkokul öğrencilerinin çoğunun okula velileri tarafından getirilmeleri nedeniyle okul müdürünün velilere de hitap ettiği gözlenmiştir. Okul müdürünün velilere hitabında; öğrencilerden istenilenleri velilerin de anlamasını sağlayarak hem anlamayan öğrencilere velilerin de anlatmasının hem de istenilenlerin velilerin desteğiyle yerine getirilmesinin beklendiği dikkat çekmektedir.

Çelenk'in (2003) çalışmasında ailelerin destekleyici bir tutum sergilemesinin öğrenci başarısını olumlu yönde etkilediği ifade edilmektedir. Ayık ve Ada'nın (2009) çalışmasında okulların, "etkili okul" olabilmesi için velilerin desteğinin gerekli olduğu vurgulanmaktadır. Özgan ve Aydın'ın (2010) çalışmasında ise velilerle okul yönetimi arasındaki iletişimin, sadece problem durumlarında desteklerinin beklenmesi şeklinde olmasının veliler tarafından eleştirildiği görülmektedir. İlkokulun okul müdürünün, etkili bir yönetim için velilerin desteğini önemsediği ve kararlarının uygulanması için onların desteğini beklediği görülmektedir. Diğer yandan okul yönetimi ile veliler arasındaki iletişimin, sadece problemlerin çözümünde velilerin desteklerinin beklenmesi şeklinde olduğuna ilişkin net bir şey söylemek ise mümkün görünmemektedir. 
EXTENDED ABSTRACT

\title{
Discourse Analysis of The Speeches of School Principals In Flag Ceremonies
}

\author{
Ramazan Asar / Ahmet Arifoğlu \\ Hacettepe University
}

In Turkey in public and private schools, prior to the course starting in the first week and after the end of the last course is compulsory flag ceremony. All students, teachers and staff at the school are obliged to attend the flag ceremonies. Teachers can conduct the ceremony together with the school administrators. However, the principal is responsible for conducting the ceremony. It is not compulsory for the school principal to give speeches at the flag ceremonies. However, if he is to talk, he must complete his speech before the flag ceremony. Although the school principal does not have to give speeches in these ceremonies, speaking on various topics makes the school principal say important.

School principals use different channels for communication and evaluate different possibilities. Flag Ceremony is a communication channel that school principals consider. Communication, which expresses both understanding and transfering of ideas and discourses, constitutes a large part of school life. In organizations, the most time among the general workload of the managers is communication. Therefore, the school director needs to demonstrate effective communication for effective management at school.

Everything the administrator do involves communication. Because an administrator cannot formulate and decide without a knowledge flow. Since the implementation of decisions related to management is provided through communication, how managers communicate with people also reveals their management style. Many different researches about the communication style of managers show the importance of communication style in terms of management. It shows how the school principal used the flag ceremonies, and how he wanted to communicate with pe- 
ople. The way that school principals convey their messages shows the way they communicate and thus the style of management.

In this study, it is aimed to examine the school principals' speeches at the flag ceremonies, which must be held before the classes on Mondays and after the classes on Fridays. For this purpose, a qualitative research approach has been adopted. Discourse analysis technique was used to examine the topics of school principals and how they convey their messages. Discourse Analysis is a qualitative approach that illustrates what social reality is said to be, rather than just showing what a person thinks. Discourse Analysis provides an understanding of the function of language and discourse in order to reveal the unspoken and unknown aspects of human behavior.

The study was carried out in Ankara in the second term of the 20152016 academic year. For the study group, a school was established from the districts of Altındağ, Gölbaşı and Keçiören. Schools are in primary, secondary and high school levels respectively. The data were collected by the researchers by visiting the schools and observing and recording. The collection of research data shows the ability to measure unresponsive. Unresponsive measurements are measurement groups where the people studied are unaware that they are part of a study. In this way, it is aimed to gather research data in its naturalness. In the study, a qualitative approach, the discourse analysis technique was used to determine the theme of the ceremonies of the school principals and the manner and order of the ceremonies.

As a result of the research, it was seen that school principals used these ceremonies to make speeches for specific purposes. Since the school principals had no obligation to speak, it was seen that they did not give speeches at every ceremony. The fact that school principals do not feel obliged to speak at all times makes the conversations important. At the ceremonies, the highest number of speakers was the principal of the high school and the least speaker was the principal of the middle school.

It was concluded that school principals in ceremonies gave speeches about making announcements, making warnings and providing discipline. It was observed that the flag ceremonies were evaluated effectively in order to make announcements on previously planned issues. School principals have warnings to draw attention to problems in their speec- 
hes. The fact that the school principals tried to take measures to prevent negativity by giving instructions, shows that the solution of the problems is given priority. School principals, in their speeches, put emphasis on discipline. School principals expect students and teachers to follow the rules without any warning.

It was observed that the address of the school principals and the forms of addressing varied. The principle of the primary school is threatening, while the high school principal uses an instructive language while the middle school principal uses a respectful language. The principal of the elementary school sent messages by intimidating the students with punishment. The principle of the middle school conveyed his messages through persuasion by stating the reasons for what he wanted in his speeches. The high school principal conveyed his messages using an empirical language and his language was sometimes offensive to people.

School principals have tried to solve some problems in school with their speeches. Moving the problems to the conversations at the flag ceremonies shows that these cannot be solved by communication within the organization. Conversations and warnings of teachers, especially in ceremonies, indicate the lack of communication between the principal and the teachers. Normally, issues addressed to teachers require twoway communication. However, the school principal tries to solve this with one-way communication.

The flag ceremonies that bring all students and teachers together are tried to be evaluated by the school principals. All the students, teachers and parents who are difficult to come together at regular times, ceremonies are used as a cost-effective and effective means of communication to evaluate. The primary school principal seems to care about the support of parents for effective management and expect their support for the implementation of their decisions. School principals do not ignore communication, which is a management process. 


\section{Kaynakça/References}

Asar, R. ve Çelikten, M. (2016). Evaluation of the attitudes towards women managers working at educational institutions. OPUSUluslararası Toplum Araştırmaları Dergisi, 6(10), 8-19.

Asar, R. ve Çelikten, Y. (2016). Shadowing a woman administrator: A Turkish case. Universal Journal of Management 4(11), 607-614.

Asar, R. (2018). Çalışanın işe tutulması. Çukurova Üniversitesi Sosyal Bilimler Enstitüsü Dergisi, 27(2), 33-43.

Aydın, M. (2014). Ĕ̆itim yönetimi. Ankara: Gazi Kitabevi.

Ayık, A. ve Ada, Ş. (2009). İlköğretim okullarında oluşturulan okul kültürü ile okulların etkililiği arasındaki ilişki. Gaziantep University Journal of Social Sciences, 8(2), 429-446.

Balcı, A. (2013). Sosyal bilimlerde araştırma yöntem, teknik ve ilkeler. Ankara: Pegem Akademi.

Baş, T. ve Akturan, U. (2013). Nitel araştırma yöntemleri Nvivo ile nitel veri analizi, örnekleme, analiz, yorum. Ankara: Seçkin Yayıncllı.

Bektaş, M. (2014). Yönetim tarzlarmmn örgütlerdeki informal iletişim kanallarına etkisi: Burdur ili kamu kurumları örneği. Yayınlanmamış Doktora Tezi. Süleyman Demirel Üniversitesi, Sosyal Bilimler Enstitüsü, Isparta.

Brown, G. ve Yule G. (1983). Discourse analysis. Cambridge: Cambridge University Press.

Çelenk, S. (2003). Okul başarısının ön koşulu: Okul aile dayanışmas1. İlköğretim online, 2(2), 28-34.

Çelikten, M. (2001a). Okul müdürlerinin değişim yönetimi becerileri. Eğitim ve Bilim, 26(119), 14-19.

Çelikten, M. (2001b). Etkili okullarda karar süreci. Erciyes Üniversitesi Sosyal Bilimler Enstitüsü Dergisi, 1(11), 1-12.

Çelikten, M. (2004). Okul müdürü koltuğundaki kadınlar: Kayseri ili örneği. Erciyes Üniversitesi Sosyal Bilimler Enstitüsü Dergisi, 1(17), 91-118.

Erkuş, A. ve Günlü, E. (2009). İletişim tarzının ve sözsüz iletişim düzeyinin çalışanların iş performansına etkisi: Beş yıldızlı otel işletmelerinde bir araştırma. Anatolia: Turizm Araştırmaları Dergisi, 20(1), 724. 
Elliott, R. (1996). Discourse analysis: exploring action, function and conflict in social texts. Marketing Intelligence \& Planning, 14(6), 65-68.

Gökçe, D. ve Baskan, G. A. (2012). Eğitim denetçilerinin iletişim becerileri. Hacettepe Üniversitesi Eğitim Fakültesi Dergisi, (42), 200-211.

Günenç, E. (2014). Nlp (nöro linguistik programlama) eğitiminin sağllk yöneticilerinin iletişim tarzı, sözsüz iletişim düzeyi ve kişiler arası iletişim süreci üzerindeki etkileri (Tire devlet hastanesinde bir uygulama). Yayınlanmamış Yüksek Lisans Tezi. Beykent Üniversitesi, Sosyal Bilimler Enstitüsü, İstanbul.

Gür, T. (2013). Post-modern bir araştırma yöntemi olarak söylem çözümlemesi. Zeitschrift für die Welt der Türken/Journal of World of Turks, 5(1), 185-202.

Hoy, W. K. ve Miskel, C. G. (2012). Eğitim yönetimi: Teori, araştırma ve uygulama (Çev. Ed.: S. Turan). Ankara: Nobel Akademik Yayınc1lik.

Jones, R. H. (2012). Discourse analysis. London and New York: Routledge.

Jorgensen, M. W. ve Phillips, L. J. (2002). Discourse analysis as theory and method. London: Sage Publications.

Karakaya, M. ve Uluğ, F. (2011). Mesleki ortaöğretim kurumlarında yetki devri. Education Sciences, 6(1), 744-759.

Karcıoğlu, F., Timuroğlu, K. ve Çınar, O. (2009). Örgütsel iletişim ve iş tatmini ilişkisi bir uygulama. İstanbul Üniversitesi İşletme İktisadi Enstitüsü Dergisi-Yönetim, 67, 59-76.

Lunenburg, F. C. ve Ornstein, A. C. (2013). Eğitim yönetimi (Çev. Ed.: G. Arastaman). Ankara: Nobel Yayınları.

Milli Eğitim Bakanlığ1 (2007). Web Sayfası: http://mevzuat.meb.gov.tr/html/ 2594 0.html (Erişim Tarihi: 12.05.2016).

Morgan, A. (2010). Discourse analysis: An overview for the neophyte researcher. Journal of Health and Social Care Improvement, 1, 1-7.

Neuman, W. L. (2013). Toplumsal araştırma yöntemleri: nitel ve nicelik yaklaşımlar (Çev.: S. Özge). İstanbul: Yayın Odası Yayınları.

Özdemir, M. (2010). Nitel veri analizi: Sosyal bilimlerde yöntembilim sorunsalı üzerine bir çalışma. Eskişehir Osmangazi Üniversitesi Sosyal Bilimler Dergisi, 11(1), 323-343. 
Özgan, H. ve Aslan, N. (2008). İlköğretim okul müdürlerinin sözlü iletişim biçiminin öğretmenlerin motivasyonuna etkisinin incelenmesi. Gaziantep University Journal of Social Sciences, 7(1), 190-206.

Özgan, H. ve Aydın, Z. (2010). Okul-aile işbirliğine ilişkin yönetici, öğretmen ve veli görüşleri. 9. Ulusal Sinıf Öğretmenliği Eğitimi Sempоzуuтu, 20-22 Mayıs 2010, Elazı̆̆. (s. 802-811).

Phillips, N. ve Hardy, C. (2002). Discourse analysis. Londra: Sage Publications.

Potter, J. ve Wetherell, M. (1987). Discourse and social psychology: Beyond attitudes and behaviour. London: Sage Publications.

Robbins, S. P., Decenzo, D. A. ve Coulter, M. (2013). Yönetimin esaslarn (Çev. Ed.: A. Öğüt). Ankara: Nobel Yayın Dağıtım.

Robbins, S. P. ve Judge, T. (2013). Örgütsel davranış (Çev.: İ. Erdem). Ankara: Nobel Yayın Dağıtım.

Sözen, E. (1999). Söylem: belirsizlik, mübadele, bilgi, güç ve refleksivite. İstanbul: Paradigma Yayınları.

Şahin, A. E. (2000). İlköğretim okulu müdürlerinin yeterlikleri. Kuram ve Uygulamada Egitim Yönetimi Dergisi, 6(2), 243-260.

Şahin, M. (2013). Okul kültürünün bir öğesi olarak okul törenleri. Milli Ĕ̆itim Dergisi, 43(199), 169-185.

Şekerci, M. ve Aypay, A. (2009). İlköğretim okulu yöneticilerinin yönetim becerileri ile grup etkililiği arasındaki ilişki. Kuram ve uygulamada eğitim yönetimi, 57(57), 133-160.

Tanrıverdi, H., Adıgüzel, O. ve Çiftçi, M. (2010). Sağlık yöneticilerine ait iletişim becerilerinin çalışan performansına etkileri: Kamu hastanesi örneği. Süleyman Demirel Üniversitesi Sosyal Bilimler Enstitüsü Dergisi, (11), 101-122.

Tonkiss, K. (2006). Analysis text and speech: content and discourse analysis. C. Seale (Ed.). Researching Society and Culture içinde (s. 367-383). London: Sage Publications.

Treadwell, D. (2013). Introducing communication research: Paths of inquiry. London: Sage Publications.

Türk Dil Kurumu (2016). Web Sayfası: http://www.tdk.gov.tr/index.php?option= com bts $($ Erişim Tarihi: 13.05 .2016$)$. 
Üstüner, M. (2016). Algılanan müdür yönetim tarzı ölçeğinin geçerlik ve güvenirlik çalışması. Kuram ve Uygulamada Ĕ̆itim Yönetimi, 22(3), 429-457.

Yin, R. K. (2011). Qualitative research from start to finish. New york and London: The Guilford Press.

\section{Kaynakça Bilgisi / Citation Information}

Asar, R. ve Arifoğlu, A. (2018). Bayrak törenlerinde okul müdürlerinin yaptığı konuşmaların söylem analizi. OPUS-Uluslararası Toplum Araştırmaları Dergisi, 9(16), 375-400. DOI: 10.26466/opus.476594 